\title{
Europeanised International Law and Administrative and Constitutional Courts in EU Member States: Navigating the Global Legal Waters of Luxembourg (CJEU), Strasbourg (ECtHR) and The Hague (ICJ)
}

Introduction

In a globalised world, administrative and constitutional courts everywhere are increasingly required to apply international law, necessitating a delicate balancing act between national law and domestic policies and international law, sometimes originating from dictations by international tribunals such as the International Court of Justice. This is even more the case for such courts in the EU, adding to the equation "Europeanised" international law as laid down by the Court of Justice of the European Union and the European Court of Human Rights.

The article analyses these challenges faced by constitutional and administrative courts in EU Member States when applying international public law, international human rights law and international private law. In discussing each field, the debate includes real and hypothetical examples and case studies, highlighting potential points of conflicts and convergence between the relevant case law.

Utilising the findings of the analysis, the paper attempts to draw a road map for European judges to manoeuvre the international legal field as they seek the most appropriate balance between domestic law, EU law and the decisions of the tribunals.

2. State courts and international law and international tribunals:

setting up the framework

Understanding the way European constitutional and administrative courts operate with relation to international law necessitates an initial discussion of the overall framework of courts as actors on the transnational stage.

1 Itai Apter, LL.B. University of Haifa (2006); LL.M. (New York University); University of Haifa (Ph.D. Candidate 2019). 
In particular, it is imperative to comprehend the function of courts as transnational political and legal strategic actors via both international law instruments and supranational courts ${ }^{2}$.

In the early days, at the advent of municipal state courts serving as adjudicators of private law disputes, and later in the capacity of resolving disputes between sovereigns and subjects, it was to be expected that courts limit themselves to the self-contained domestic legal systems in the form of a local code or precedent ${ }^{3}$. In some cases, access to specific courts was determined by social class, as for example the use in England of royal courts and common law by knights and noblemen and the use of other kinds of courts by merchants ${ }^{4}$.

This was particularly the case for disputes between subjects and sovereigns when the controlling rule was that the "king can do no wrong"'. Under that logic, challenging the sovereign's decisions in court seemed to be almost impossible, ${ }^{6}$ and there was seemingly little relevance, if any, to transnational legal developments.

Such an outcome might be associated with the fact that in those early times, prior to the founding moments of international law, the law of nations was almost conceptually non-existent ${ }^{7}$. However, it seems more accurate to link this to periodic perceptions of law as a domestic self-contained regime dictated by the absolute sovereign ${ }^{8}$ or based on religious precepts 9 .

Progress in governance modalities supporting the concept of separation of powers seems to have provided municipal state courts with flexibility

2 L.T. Putnam, Courts without Borders: Law, Politics, and US Extraterritoriality, Cambridge University Press, 2016, p. 71.

3 See, for example, in relation to China, P. Buckley Ebrey, A. Walthall, Pre-Modern East Asia to 1800: A Cultural, Social, and Political History, Cengage Learning 2014, p. 189.

4 L.M. Friedman, The Legal System: A Social Science Perspective, 1987, p. 198.

5 G.W. Pugh, "Historical Approach to the Doctrine of Sovereign Immunity", Louisiana Law Review, vol. 13, no. 3, 1953, p. 476, p. 479.

6 The historical explanation to this idea can be dated back to the time of JeanJacques Rousseau (eighteenth century) noting that because the individual person is part of the sovereign he or she cannot have diverging interests. 'Lai Oshitokunbo Oshisanya, An Almanac of Contemporary Judicial Restatements - With Commentaries The Basebook, $2^{\text {nd }}$ ed. 2015, p. 378.

7 The emergence of the law of nations (the early form of international law) can be backtracked to the late seventeenth century; see O. Bakircioglu, "The Right to Self-Defence in National and International Law: The Role of the Imminence Requirement", Indiana International \& Comparative Law Review, vol. 19, 2009, p. 1, p. 5.

8 This was the idea expressed, for example, by Hobbs. See "Sovereignty", The Stanford Encyclopedia of Philosophy, https://plato.stanford.edu/entries/sovereignty/, 25 March 2016 (accessed 23.9.2018).

9 See, for example, in relation to commercial law which was arguably influenced by Christian Canon law and so-called "church values", D.J. Callahan, "Medieval Church Norms and Fiduciary Duties in Partnership", Cardozo Law Review, vol. 26, 2004, p. 215, p. 234-237. 
in exercising judicial analysis ${ }^{10}$, alongside the establishment of a mechanism which afforded citizens and subjects tools to facilitate challenges to government actions ${ }^{11}$. Although this opened up avenues for courts to use sources outside of restricted legal regimes, at least initially courts were reluctant to look at other legal systems, let alone supranational theories and ideas, which were not expressly embodied in law ${ }^{12}$.

Such an approach was understandable, as the tendency of courts was to apply their own familiar legal concepts to resolve local and domestic disputes before them, even when international treaties were concerned ${ }^{13}$. Recognising changes in the mode of thinking of some courts, it is important to bear in mind that even today, when it comes to interpretation of international treaties, municipal courts still take into account the colour of domestic legal system lending contemporary legitimacy to such an approach $^{14}$.

Growth in international trade and early globalisation have brought forward a natural development of domestic courts, in particular in the case of higher national courts faced with questions pertaining to cases with international implications like the transatlantic slavery trade ${ }^{15}$, piracy ${ }^{16}$ and diplomatic immunity ${ }^{17}$. The need to resolve disputes raising questions outside of the scope of domestic law necessitated exploration of international treaties, or early concepts of the law of nations, in order to fill the vacuum in domestic law. This trend was especially apparent for US

10 In the formation of the United States, the intention was different as the founders viewed judicial discretion in a negative perspective due to their experience with royal courts; J.F. Manning, "Textualism and the Equity of Statute", Columbia Law Review, vol. 101, 2001, p. 1, p. 61.

11 Today, this is the concept referred to as judicial review which can provide remedy for complaints on maladministration, A.L. Suere, Administrative Litigation in England and Wales, in: Administrative Litigation Systems in Greater China and Europe, Y. Li (ed.), 2014, p. 161, p. 163.

12 See, for example, an analysis of nineteenth-century English case law, M. Lobban, "English Approaches to International Law", in: Time, History and International Law, M.C.R. Craven, M. Fitzmaurice, M. Vogiatzi (eds.) 2006, p. 65, p. 77.

$13 \mathrm{M}$. Weibel, Principles of Treaty Interpretation: Developed for and Applied by $\mathrm{Na}$ tional Courts, in: The Interpretation of International Law by Domestic Courts: Uniformity, H.P. Aust, G. Nolte (eds.), 2016, p. 9, p. 31.

14 Ibidem, p. 36.

15 The Antelope, 23 U.S. (10 Wheaton) 5, 66 (1825). In this case, the US Supreme Court questioned the anomaly between the prohibition of slavery in the US and the legality of the slavery trade in the law of the nations.

16 For an analysis of early English law on piracy, see Bruce A. Elleman, "Foreword" in Piracy and Maritme Crime - Historical and Modern Case Studies, B.A. Elleman, A. Forbes, D. Rosenberg (eds.) 2010, V-VII.

17 M.J. Langley Hardy, Modern Diplomatic Law, Manchester 1968, p. 56-57. 
domestic courts which developed case law on the law of nations which is still relevant today ${ }^{18}$.

Applying international law in cases involving international or crossborder elements might not be considered an exceptional development as courts seemed not to have a true choice in the matter due to the lack of relevant domestic law. However, this utilisation of international law was of significance as it allowed courts to become familiar with international legal concepts, which in many cases presented principles and theories distinct from domestic law and legal perceptions.

International law in its modern form is considered to have evolved in the post-WWII era ${ }^{19}$. Following the collapse of the League of Nations and the international legal system it has tried to establish and maintain, the focus of the international community shifted to creating international legal obligations with direct impact on states, aiming to create a transnational legal order $^{20}$.

In that regard, some leading examples include the advent of international human rights treaties like the 1966 International Convention on Political and Civil Rights and the 1966 International Convention on Cultural, Economic and Social Rights, and subsequent similar instruments ${ }^{21}$. For almost the first time, international treaties focused on relationships between sovereigns and subjects imposing obligations on governments to ensure protection for nationals on issues ranging from arbitrary detention, discrimination, education and various other rights ${ }^{22}$.

Understating this, it is not surprising that domestic courts might have to engage with these treaties when addressing relevant disputes between

18 The term "law of nations" was relatively frequently used by US courts in the period between 1776 and 1900. According to at least one study, it was referred to 1,752 times in that period, W.J. Moon, "The Original Meaning of the Law of Nations", The Virginia Journal of International Law, vol. 56, 2016, p. 51, p. 61.

19 This can be mainly associated with the work of the United Nations on the development of a core body of international treaties to regulate international relations. For a brief analysis, see UN Website, International Law and Justice, http://www.un.org/en/ sections/issues-depth/international-law-and-justice/ (accessed 26.9.2018).

20 It is important to note that while various norms were created, this did not mean that these were considered always effective and legitimate. For a discussion focusing on this perspective, see M. Kumm, “The Legitimacy of International Law: A Constitutionalist Framework of Analysis", The European Journal of International Law vol. 15, no. 5, 2004, p. 907, p. 909-917.

21 These two conventions paved the way for what is defined today as international human rights law. For a comprehensive list of current relevant treaties, see UN OHCR Website https://www.ohchr.org/EN/ProfessionalInterest/Pages/CoreInstruments.aspx (accessed 26.9.2018).

22 See the various provisions of the 1966 International Convention on Political and Civil Rights (ICCPR), 16 December 1966, United Nations, Treaty Series, vol. 999, p. 171, and the 1966 International Convention on Cultural, Economic and Social Rights (ICESCR), 6 December 1966, United Nations, Treaty Series, vol. 993, p. 3. 
governments and their nationals ${ }^{23}$ although for certain conventions in some world regions it is not always the case ${ }^{24}$.

Alongside the increase in global frameworks pertaining to international public law aiming to significantly enhance the regulation of relationships between states and the need for expansion of regulation of international private law related to cross-border conduct, the development of international human rights law has boosted the utilisation of international law in domestic courts.

Acknowledging that legal systems are inherently different from one another, the utilisation of international law by municipal courts can vary, ranging from reliance on international law to rejecting it and applying trumping domestic law ${ }^{25}$. Varieties in such utilisation can stem from several factors:

- Differences in the nature of legal systems; in monistic legal systems (civil law), international treaties and binding customary international law are an integral part of the domestic legal system ${ }^{26}$ while for dualistic legal systems (common law) national law overrides international law ${ }^{27}$.

- Cultural perceptions of international law and international tribunals and their binding nature on domestic level ${ }^{28}$.

- Social and economic domestic factors in the context of the engagement of the forum state with the international community.

- Subject matters of decisions in questions addressing inter alia human rights, moral values, economic or military issues.

Whatever the controlling factor in each dispute brought to resolution before the court, it is clear today that international law is relevant in various aspects of municipal, or domestic, adjudication. While the practical

23 In this respect engagement does not necessarily mean that an individual can seek a remedy for violation of a treaty right in a municipal state court. See, for example, in a decision by the Supreme Court of India, 1980 AIR 470, 1980 SCR (2) 913, 919-920.

24 In the context of the ICCPR, see B. Cali, "Influence of the ICCPR in the Middle East", in: The Human Rights Covenants at 50: Their Past, Present, and Future, D. Moeckli, H. Keller, C. Heri (eds.), 2018, p. 124, p. 139.

25 In general legal theory there is no bright-line rule on the hierarchy between international and domestic norms in case of a conflict. See A. Nollkaemper, J.E. Nijman, "Beyond the Divide", in: New Perspectives on the Divide Between National and International Law, A. Nollkaemper, J.E. Nijman (eds.), 2007, p. 341, p. 346.

26 V. Gavrilov, "Modern Russian Approaches to Correlation of International and Domestic Law”, Mediterranean Journal of Social Sciences, vol. 6, no. 5, 2015, p. 375, p. 376.

27 "Constitutional Courts and International Law: Revisiting the Transatlantic Divide", Harvard Law Review, vol. 129, 2016, p. 1362, 1367.

28 For a comparative analysis of the state of affairs in the US and France, see Martin A. Rogoff, "Symposium: French and American Perspectives Towards International Law and International Institutions: Application of Treaties and the Decisions of International Tribunals in the United States and France: Reflections on Recent Practice", Maine Law Review, vol. 58, 2006, p. 405. 
implication of this presumption is far from obvious or foreseeable and courts have much discretion in addressing international law, especially in cases when they apply the notion of "presumptive correspondence" with international instruments, the analysis demonstrates the importance of understanding how EU administrative and constitutional courts operate in this environment.

\section{Role of domestic and administrative and constitutional courts in the European Union generally and in particular in the cross-border legal context}

Before discussing the examples of implementation of international law and international case law by domestic administrative and constitutional courts in EU Member States, it is worthwhile to understand their relevance in the cross-border legal context.

Administrative Courts - the basic concept of European administrative courts is to facilitate judicial review of acts issued by administrative bodies equipping citizens with a tool to contest decisions by public authorities and to protect their rights ${ }^{29}$. In that context, the role of courts, in some systems, is also to ensure that administrative decisions are given with appropriate reasoning without which the ability of citizens to appeal against such decision can be severely limited ${ }^{30}$.

Scholarship describes the rule of administrative courts in EU Member States as focusing on the protection of citizens from arbitrary administrative decision making and ensuring the legality of the conduct of administrative bodies $^{31}$. Translating these aims into practical considerations, the role of an administrative court is to verify that an administrative body has considered the required criteria in a fair manner (assessing the administrative procedure) and to determine the consequences of failure to do $\mathrm{so}^{32}$.

29 See, for example, in the context of Hungary, P. Darak, Administrative Justice in Europe, Report of Hungary, 2, http://www.aca-europe.eu/en/eurtour/i/countries/hungary/hungary_en.pdf (accessed 28.9.2018).

30 For an extensive analysis, see I. Opdebeek, S. De Somer, "The Duty to Give Reasons in European Legal Area: a Mechanism for Transparent and Accountable Administrative Decision-Making? A Comparison of Belgian, Dutch, French and EU Administrative Law", Rocznik Administracji Publicznej, vol. 2, 2016, p. 97.

31 In the context of Germany, see D. Zu Hoenloe-Oehringen, "The Principle of Effective Legal Protection in German Administrative Law", in: The Principle of Effective Legal Protection in Administrative Law: A European Comparison, Z. Szente, K. Lachmayer (eds.), Taylor \& Francis Ltd 2017, p. 122-157.

32 See, for example, in respect of detention in the context of illegal immigration, L. Muzi, "Administrative Due Process of Law in the Light of the Jurisprudence of EU Courts: A Quantitative and Qualitative Analysis", in: Research Handbook on EU 
Inherently, legal administrative frameworks differ between EU Member States but two approaches can be discerned as regards the right of standing; one that limits such rights to those directly wronged by a decision of an administrative body and a system which allows anyone with a legitimate interest in the decision to ask an administrative court to review it ${ }^{33}$.

Other important elements in the administrative law and court framework, with potential relevance for the cross-border global context include: types of decisions which can be reviewed by the courts (some governmental acts, regulatory and statutory measures, public tenders); correspondence with "superior" rules; equality; legitimate expectation of individuals; impartiality; proportionality; transparency, and fairness ${ }^{34}$.

Overall, the principle notion of the operation of administrative courts can be viewed as a means to enhance the administrative quality and legitimacy of the decision ${ }^{35}$, to deter administrative bodies from ignoring the principles of legality ${ }^{36}$ and fairness of the administrative process ${ }^{37}$. These, and other, components are embodied in the administrative court system as it preforms its role within the checks and balances and separation of powers framework in democratic EU Member States.

The features of administrative courts briefly detailed above can be of significant relevance in the international legal cross-border context, complementing the role of such courts in the EU legal system (which the paper does not elaborate on). Relevance is mostly derived from the notion of the impact of a transnational legal order, which domestic law incorporates, especially in the monistic EU Member States.

Assuming the "transnational global nature" of the legal structure of domestic law in EU Member States, the potential for involvement of administrative courts in matters pertaining to cross-border legal international (rather than European) regimes is substantial. As most countries, including

Administrative Law, C. Harlow, P. Leino, G. della Cananea (eds.), Edward Elgar Pub, 2017, p. 468-489.

33 For examples of approaches, see for France (a limited rights of standing), European Parliament Report - Standing Up for Your Right(s) in Europe Locus Standi Country Reports Annex IV (2012), p. 96-97 and a more "liberal" approach in England and Wales, p. 60-61.

34 J.-M. Woehrling, "Judicial Control of Administrative Authorities in Europe: Toward a Common Model", Hrvatska Javna Uprava, god. 6. br. 3, 2006, p. 35, p. 51-54.

35 Ibidem, p. 36.

36 For a comparative analysis of the application of the principles of legality in administrative courts in Europe, see J.-M. Woehrling, Protecting Legality: Public administration and judiciary in EU countries. How to conciliate executive accountability and judicial review?, 2009, http://www.sigmaweb.org/publications/42755351.pdf (accessed 5.10.2018).

37 The administrative judicial system in itself should also be based on a fair trial. For an analysis in the context of Poland, see A. Skoczylas, M. Swora, "Administrative Judiciary in Poland in Search for Fairness and Efficiency - An Overview", Transylvanian Review of Administrative Sciences, vol. 19 E/2007, p. 116-125. 
EU Member States, are likely to comply with international law for legal or strategic, reasons ${ }^{38}$, the transitional influence on domestic administrative decisions can, at times, be quite considerable.

Considering also the growing phenomena that some call "global administrative law"39, domestic administrations often face the need of adapting domestic regulatory frameworks to transnational standards, hence impacting regulation in a variety of fields and sometimes resulting in high adaptation $\operatorname{cost}^{40}$.

Merging the analysis of the role of administrative courts in EU Member States with this global picture, even if there are signs of limitations on legal transnationalism and reversion to legal sovereignty ${ }^{41}$, it is apparent that administrative courts can be required to review and control many decisions and governmental measures originating from a global or transnational legal order ${ }^{42}$.

In cases where administrative courts are faced with these types of measures, they might find themselves required to determine, as part of the process of reviewing the legality of the administrative process, whether the administrative practice was, or was not, in violation of international obligations ${ }^{43}$. Even assuming that in many cases the global interpretation of the treaties would not be controlling and the courts tend to follow domestic legal frameworks, the international element would still have been apparent.

Similarly, administrative courts can be asked to review whether administrative acts correspond with decisions of international bodies operating under the auspices of international treaties ${ }^{44}$. Adjudicating disputes on this

38 A.T. Guzman, "A Compliance Based Theory of International Law", California Law Review, vol. 90, 2002, p. 1823, p. 1866.

39 For an expansive overview, see Sabino Cassese, Elisa Deltario, "Introduction" in Global Administrative Law: The Casebook, S. Cassese, B. Carotti, L. Casini, El. Cavalieri \& E. MacDonald (eds.), 2012, p. 1-24.

40 For an analysis in the context of Ukraine and EU standards, see J. Langbein, Transnationalisation and Regulatory Change in the EU's Eastern Neighbourhood, London and New York: Routledge 2015, p. 76-80.

41 One example in the European context is the Brexit process (the UK's decision to exit the EU). For an analysis of the implication of Brexit on transnational law, see R. Michaels, "Does Brexit Spell the Death of Transnational Law?", German Law Journal, vol. 17, 2016, p. 52.

42 In some instances, courts are required to directly review the transnational measures in themselves; M. Benedetti, "The Conseil d'Etat and Schengen" in Global Administrative Law: The Casebook, S. Cassese, B. Carotti, L. Casini, E. Cavalieri \& E. MacDonald (eds.), 2012, p. 199, p. 212-213.

43 This could be the case where there is no conflict with domestic law as domestic courts serve as a de-facto "instrument" of international law. P.-M. Dupuy, "The Unity of Application of International Law at the Global Level and the Responsibility of Judges", European Journal of Legal Studies, vol. 1(2), 2007, p. 1, 2.

44 For an analysis of examples from Poland in this respect, see A. Wyrozumska, "Poland" in International Law and Domestic Legal Systems: Incorporation, Trans- 
question often involves determining the binding effect of decisions of global institutions ${ }^{45}$, quite a challenging task in an international system without an overall and overbroad "global supreme court" with overriding powers, jurisdiction or enforcement mechanisms.

Constitutional Courts - constitutional courts in EU Member States can be considered as principle actors in the framework of constitutional democracy central to their government and administration ${ }^{46}$.

The main role of the courts, as defined in various national constitutions, is to, inter alia, preserve the rule of law; fundamental rights; equality, protection of minorities; and human dignity ${ }^{47}$. Entrusting constitutional courts with these functions is often associated with the need of protection mechanisms from the "tyranny of the majority" in democratic societies ${ }^{48}$. In the context of emerging democracies, as is the case for newer EU members from Central and Eastern Europe, the role of constitutional courts becomes even more essential in the transformation from communism to constitutional democracies ${ }^{49}$.

Differently from the common law system of constitutional review by all judicial instances entrusted with reviewing the constitutionality of measures taken by executive and legislative bodies ${ }^{50}$, constitutional courts in most EU Member States are specialised courts solely focusing on constitutional issues ${ }^{51}$. In some of EU systems, constitutional courts are often engaged in balancing between different constitutional rights in what can be viewed

formation and Persuasion, D. Shelton (ed.), Oxford Scholarship Online, 2011, p. 468, p. 497-499.

45 The fact that cases where domestic courts consider as binding decisions by international tribunals, for example, are rare, does not mean that these do not necessarily have relevance in domestic adjudication of disputes; A. Reinisch, Introduction in The Privileges and Immunities of International Organizations in Domestic Courts, A. Reinisch (ed.), 2013, p. 14-15.

46 J. Komárek, "The Place of Constitutional Courts in the EU", European Constitutional Law Review, vol. 9, 2013, p. 423.

47 For an analysis of constitutional court case law in Germany in respect of the right to human dignity, see Ch. Enders, "The Right to have Rights: The concept of human dignity in German Basic Law", Revista de Estudos Constitucionais, Hermenêutica e Teoria do Direito, vol. 2(1), 2010, p. 1-8.

48 This is also the role of the constitution in itself. See R. Maruste, "The Role of the Consitutional Court in Democratic Society”, Juridica International, XIII, 2007, p. 8-9.

49 This transformation can be called a move from underenforced constitutions to those which are actually enforced. See R. Titel, "Post-Communist Constitutionalism: A Transitional Perspective”, Columbia Human Rights Law Review, vol. 26, 1994, p. 167, p. $173-174$.

50 In the context of the US system see G.F. de Andrade, "Comparative Judicial Review”, Journal of Constitutional Law, vol. 3(3), 2001, p. 977, p. 979.

51 Ibidem. 
as a deliberative process in the context of "communicative arrangements" between bodies in the domestic governmental system ${ }^{52}$.

Translating the overall framework described above into its practical manifestation, several main functions of constitutional courts in EU Member States can be noted: verifying whether national legislation corresponds with the constitution ${ }^{53}$; exercising constitutional review on state actions ${ }^{54}$; and addressing jurisdictional issues relating to relationship between $\mathrm{EU}$ and domestic laws ${ }^{55}$.

Constitutional courts can, in some EU Member States, consider both individual complaints concerning violations of constitutional rights and referrals from courts (or the legislature) on the constitutionality of governance-related measures (as noted, decisions and legislation) ${ }^{56}$. This relatively expansive framework is important to bear in mind in the crossborder legal context as it has a potential to expose constitutional courts to various issues with relevance for the international legal order.

In addition to similar relevant issues for administrative courts, under the framework briefly described above, in the global cross-border context, the main traditional role of constitutional courts in EU Member States is in relation to the European Convention on Human Rights (ECHR $)^{57}$. While this Convention is binding on its EU Member States, adjudication of domestic measures in its light (complemented by the jurisdiction of the European Court of Human Rights to be further discussed in the next section) can be significantly associated with international human rights $\operatorname{law}^{58}$.

52 J. Komárek, "National Constitutional Courts in the European Constitutional Democracy", International Journal of Constitutional Law, vol. 12(3), 2014, p. 7-9.

53 In the context of the French Constitutional Court see C. White, National Constitutional Courts and the EU The Evolution of the Conseil Constitutionnel and the Bundesverfassungsgericht, 2014, p. 5.

54 A. Eilers, The Binding Effect of Federal Constitutional Court Decisions Upon Political Institutions, 2003, p. 3, https://www.venice.coe.int/webforms/documents/default. aspx?pdffile=CDL-JU(2003)018-e (accessed 16.10.2018).

55 For a brief analysis, see M. Cartabia, Constitutional Courts between Constitutional Law and European Law, https://www.cortecostituzionale.it/documenti/relazioni_internazionali/relazioneCartabia.pdf (accessed 16.10.2018).

56 For a list of jurisdictions where such individual complaints are possible, see Study on Individual Access to Constitutional Justice (2010), https://www.venice.coe. int/WebForms/documents/default.aspx?pdffile=CDL-AD(2010)039rev-e (accessed 16.10.2018).

57 This role predated the accession of the Member States to the EU. See, for example, in respect of Romania, Constitutional Courts and European Integration - Science and Technique and Democracy, 2005, p. 169.

58 See, for example, in respect of the practice of the Constitutional Court in Latvia, I. Ziemele, The Significance of the European Convention for the Protection of Human Rights and Fundamental Freedoms in the Case-Law of the Constitutional Court of the Republic of Latvia (2 October 2017), http://www.satv.tiesa.gov.lv/en/articles/the-signi- 
Recognising that the human rights framework is the most relevant for constitutional courts, it is important to realise that in a globalised transnational world not only legal and physical boundaries can be blurred but also those of legal disciplines ${ }^{59}$. In that respect, private international law matters as well as those relating to public international law can often come up in adjudication of constitutional human rights issues ${ }^{60}$, creating additional challenges for contemporary constitutional courts in EU Member States.

As the analysis demonstrates, international law can be relevant in the work and operation of administrative and constitutional courts, often inherently intersecting with EU law-related issues. This intersection is very interesting from a theoretical perspective but as the paper is oriented towards practical dilemmas and solutions, the focus of the next section will be on potential conflicts between international and European adjudicative bodies (CJEU, ECtHR, ICJ) as these can play out in domestic adjudication in administrative and constitutional courts in EU Member States.

\section{International law conflicts with European (EU and $\mathrm{COE}$ ) law in domestic European administrative and constitutional courts}

Conflicts between the different applicable regimes when international law issues come before administrative and constitutional courts in EU Member States can be varied as cases and circumstances ${ }^{61}$. Far from attempting to present a full and exhaustive list of possible situations or even offering a detailed analysis of relevant cases, the aim of the following analysis is to illustrate issues and dilemmas which might arise in three potential scenarios from three international law related fields, based on examples and dilemmas faced by these European courts in recent years.

International Public Law - one of the most contentious issues in domestic litigation involving international public law is the question of

ficance-of-the-european-convention-for-the-protection-of-human-rights-and-fundamental-freedoms-in-the-case-law-of-the-constitutional-court-of-the-republic-of-lat$\mathrm{via} /$ (accessed 16.10.2018).

59 Global Security Engagement: A New Model for Cooperative Threat Reduction, 2009 , p. 5.

60 See, for example, in the context of a decision by a German court as early as 1971, L.R. Kiestra, The Impact of the European Convention on Human Rights on Private International Law, 2014, p. 4.

61 See, for example, the discussion of the approach of the Court of Justice of the European Union in respect of potential conflicts with decisions of international tribunals, M. Parish, "International Courts and the European Legal Order", European Journal of International Law, vol. 23(1), 2012, p. 141. 
sovereign immunity and the possible avenues available for litigation against states or against state officials ${ }^{62}$.

In recent decades, there has been emerging customary international law based on restrictive theories of immunity, based on the principle that a state (and its officials) enjoy immunity from litigation unless certain exceptions apply, ranging from torts occurring in the forum state, to commercial activity and employment-related suits under some circumstances ${ }^{63}$. In that respect, there is even a universal Convention, not yet ratified, which although lacking the status of customary international law might reflect some common practices ${ }^{64}$. Similarly, since 1972, there has been a European foreign state immunity regime to which most European states are members, which also includes such concepts ${ }^{65}$.

Despite this expansive treatment of foreign state immunity in international legal regimes, the issue still presents challenges when it comes to litigation before domestic courts. One of the issues which has been attracting ever more attention in recent years is the alleged exception of human rights violations (sometimes termed as overriding "jus cogens") to state immunity, despite of the fact that none of the applicable regimes recognises such an exception ${ }^{66}$.

Under this framework, the common scenario is a lawsuit brought by alleged victims of an act perpetrated by a state which does not fall into one of the exceptions to sovereign immunity. Nevertheless, the plaintiff argues that because he or she alleges that the act in question violated human rights immunity should not apply ${ }^{67}$. The reasoning for such a claim is often associated with the legal argument that acts cannot be considered as state action if they are in violation of human rights norms ${ }^{68}$, coupled by

62 For a leading authority on this issue, see H. Fox, Ph. Web, The Law of State Immunity, 2013, p. 537-567.

63 One such exception is the tort exception applying to torts committed in the forum state, J. Finke, "Sovereign Immunity: Rule, Comity or Something Else", European Journal of International Law, vol. 21(4), 2011, p. 861-864.

64 UN General Assembly, United Nations Convention on Jurisdictional Immunities of States and Their Property, 2 December 2004, A/RES/59/38 (not yet in force).

651972 European Convention on State Immunity. ETS No. 074.

66 Finke, supra Note 63, 866-870.

67 See, for example, a discussion of case law in the US on this type of claim. Julian G. Ku, "The Significance of China's Views on the Jus Cogens Exception to Foreign Government Official Immunity", Duke Journal of Comparative \& International Law, vol. 26, 2016, p. 503, p. 507.

68 This is sometimes referred to as the "implicit waiver" argument, according to which states which have violated jus cogens norms implicitly waive their sovereign immunity before foreign courts. For an elaborate analysis in the context of US law, see T.A. Johnson, "A Violation of Jus Cogens Norms as an Implicit Waiver of Immunity Under the Federal Sovereign Immunities Act", Maryland Journal of International Law, vol. 19, 1995, p. 259. 
the moral argument that states must be held accountable for such violations and compensate victims affected by them.

Without getting into the merits of such an argument (which does not represent current international law $)^{69}$, the dilemmas faced by a constitutional court required to deal with this task, of balancing foreign sovereign immunity with individual rights and human rights, are significant.

Assuming such a court received the question as a referral from a lower court, the constitutional court must look at numerous sources in order to resolve the matter, including, inter alia, domestic law, including the national constitution; applicable European legal regimes in the form of the European State Immunity Convention; the European Convention of Human Rights (mainly Article 6 concerning the rights to access to judicial remedy), and decisions by the ECtHR; customary international law which every state must comply with (unless a particular state has been a persistent objector to the customary rule $)^{70}$; and last, but not least, the decisions of the ICJ.

Acknowledging the fragmented nature of international law, the task of articulating a clear and precise rule is an extremely challenging one ${ }^{71}$. In such cases, even if there is a clear rule on the issue before the court, the constitutional court still has to decide how to deal with potential conflicts between the different sources of law.

This kind of scenario can occur, for example, when the defendant state submits the case before the ICJ ${ }^{72}$, or when the plaintiff submits a motion before the ECtHR against the decision of the domestic court $^{73}$. As both institutions mostly operate on the basis of the exhaustion of local remedies rule, any decisions they render implies the decisions of the domestic courts on the same issues. Consequently, the constitutional court in an EU Member State must resolve conflicts between different decisions and interpretations,

69 See, for example, Germany v Italy; Greece Intervening (Judgment), International Court of Justice, General List, $n^{\circ} 143,3$ February 2012, para. 69.

70 M.P. Scharf, "Accelerated Formation of Customary International Law", Journal of International \& Comparative Law, vol. 20(2), 2014, p. 305, p. 309.

71 This is a challenge faced not only by domestic courts but also regional ones such as the ECtHR. For an expansive analysis, see A. Rachovitsa, „Fragmentation of International Law Revisited: Insights, Good Practices and Lessons to Be Learned from the Case Law of the European Court of Human Rights" (February 1, 2015), Leiden Journal of International Law, vol. 28, 2015, p. 863-885. Available at SSRN: https://ssrn.com/ abstract $=2597810$ (accessed 3.11.2018).

72 See, for example, the German application to the ICJ arguing against a decision by an Italian court to remove the immunity of Germany from a lawsuit filed against Germany by Greek nationals for compensation for acts related to WWII atrocities. Germany Application Instituting Proceedings on Jurisdictional Immunities of States, 23 December 2008.

73 In the Al-Adsani case, the plaintiff applied to the ECtHR to "appeal" against the decision of the UK highest court to uphold the immunity of Kuwait in a case of a claim for compensations for alleged torture submitted in the UK. Case of AL-Adsani v. The United Kingdom (Application no. 35763/97). 
even if a specific case does not reach all the instances involved. Making things even more complicated, if the case also involves question pertaining to state liability under $\mathrm{EU} \mathrm{law}^{74}$, the potential involvement of the CJEU and EU case law might lead to a multi-level conflict which must be resolved in order to adjudicate the case.

At first glance, a constitutional court in an EU Member State can just be framed in accordance with the apparent hierarchy between the different instances, and decide, for example, that because the ICJ is entrusted with interpretation of international $\mathrm{law}^{75}$, its rulings should prevail. However, as the Italian Constitutional Court has shown, when effectively overruling a decision by the ICJ on sovereign immunity with regard to lawsuits filed against Germany for human rights violations in WWII, this would not necessarily be the case if the court comes to the conclusion that its domestic constitution should be the overriding legal regime ${ }^{76}$. This might be considered a courageous decision by some ${ }^{77}$ but others have viewed the ruling as putting Italy's international obligations "in limbo worse than purgatory"78. This is significant, demonstrating the inherent difficulties in international public law adjudication before constitutional courts in EU Member States.

International Human Rights Law - similar to international public law, international human rights law in the context of litigation before EU courts can bring forth a wide variety of issues with potential conflicts between different legal regimes and legal instances.

The most prominent example in the recent decade, which would serve as a basis for the second scenario, is the question of implementation of sanctions imposed by the United Nations Security Council (UNSC) ${ }^{79}$. According to Chapter 7 of the UN Charter, all member states of the UN, which include all EU Member States, must abide by the sanctions imposed by the UNSC that, in some cases, require imposing financial sanctions and travel bans on specific individuals ${ }^{80}$. Although the process has improved,

74 For a brief analysis of state liability under EU law, see State Liability, https:// www.eurofound.europa.eu/observatories/eurwork/industrial-relations-dictionary/ state-liability (accessed 4.11.2018).

75 Article 36(2), ICJ Statute.

76 Judgment No. 238 - 2014 (IT. Const. Ct.), 22 October 222014.

77 M. Longobardo, “The Italian Constitutional Court's ruling against state immunity when international crimes occur: thoughts on decision no. 238 of 2014", Melbourne Journal of International Law, vol. 16(1), 2015, p. 255, p. 269.

78 R. Kolb, "The relationship between the international and the municipal legal order: reflections on the decision no 238/2014 of the Italian Constitution Court", Questions of International Law vol. II, 2014, p. 5, p. 15.

79 For example see Case C-402/05 P and C-415/05, P. Kadi and Al Barakaat International Foundation v. Council and Commission [2008] ECR I-6351.

80 See, for example, the sanctions imposed on Al-Qeida and ISIL. UN Security Council Website, https://www.un.org/sc/suborg/en/sanctions/1267 (accessed 10.11.2016). 
due to litigation in European courts (domestic, CJEU and the ECtHR), to include ombudsman mechanism, sanctions are still imposed in a political driven process without a judicial process ${ }^{81}$.

Under this framework, the (second) scenario is a case in which an EU Member State has decided to implement sanctions imposed by the UN, with the result of financial freezing of bank accounts of an individual who is a Member State citizen. Even assuming that some form of process took place to implement the case law of the CJEU and the ECtHR ${ }^{82}$, the listed individual still seeks to appeal against the decision by the state to impose the sanction by lodging a complaint to the an administrative court challenging the reasoning for the decision and the process applied.

When tasked with resolving the dispute, the administrative court is faced with a plethora of conflicting regimes.

On the one hand, the undisputed obligation of the EU Member State under the UN Charter (to which all Member States must adhere to), which does not allow states to divert from the sanctions, notwithstanding minimal exceptions ${ }^{83}$. Unlike for the sovereign immunity question discussed earlier, there is also no ambiguity about the binding nature of UNSC resolutions under Chapter 7 to the UN Charter ${ }^{84}$.

On the other hand, the administrative court must address the requirement to apply the ECHR (Article 6), and the applicable regimes of EU law, mainly the rights of reasoning and due process ${ }^{85}$. The dilemma is made much more acute if the court makes a referral to the $\mathrm{CJEU}^{86}$ or when

81 For an elaboration on the role and functions of the Ombudsman, see "Remarks by C. Marchi-Uhel, Ombudsperson", Security Council ISIL (Da'esh) and Al-Qaida Sanctions Committee, 2 June 2016, https://www.un.org/sc/suborg/sites/www.un.org.sc.suborg/files/02062016_cojur.pdf (accessed 10.11.2016).

82 Ibidem.

83 European Parliament Briefing - Counter-terrorist sanctions regimes Legal framework and challenges at UN and EU levels (2016), p. 2, http://www.europarl.europa. eu/RegData/etudes/BRIE/2016/589864/EPRS_BRI(2016)589864_EN.pdf(accessed 11.11.2018).

84 D. Whittle, "The Limits of Legality and the United Nations Security Council: Applying the ExtraLegal Measures Model to Chapter VII Action", European Journal of International Law, vol. 26, 2015, p. 671-672.

85 In doing so they must follow the direction set by the CJEU in this respect. See M. Payandeh, H. Sauer, "European Union: UN sanctions and EU fundamental rights", International Journal of Constitutional Law, vol. 7(2), 2009, p. 306, 311.

86 Such referrals could also arise out of cases involving third parties and not necessarily individuals or corporations targeted by UN Sanctions. See E. de Wet, Holding the United Nations Security Council Accountable for Human Rights Violations through Domestic and Regional Courts: A Case of Be Careful What You Wish For? https://www.eui. eu/Documents/DepartmentsCentres/AcademyofEuropeanLaw/CourseMaterialsHR/ HR2009/DeWet/DeWetBackgroundReading1.pdf (accessed 11.11.2018). 
the case is brought before the ECtHR ${ }^{87}$ and these instances decide that the state has contravened its obligations under the applicable European regional regimes $^{88}$. Complicating the matter even further, there could be potential referrals by the UN General Assembly to the ICJ for an advisory opinion on the binding nature of such sanctions (there does not seem to be a mechanism for ICJ jurisdiction on contentious cases in this regard ${ }^{89}$. ICJ advisory opinions do not have a legal binding effect but domestic courts might see the need to address an opinion holding that the state is in violation of its UN Charter obligations if it fails to impose UNSC-mandated sanctions ${ }^{90}$.

Administrative courts in EU Member States choosing to apply European case law over international law will be hardly to blame for going down this route ${ }^{91}$ but scholarship points out to a potential implication which these courts cannot ignore, even if the "fault" lies with regional judicial institutions including, inter alia, a "European-wide hole in the sanctions regime $^{92}$; creating difficulties in establishing an effective sanctions ombudsman regime if all decisions are considered subject to judicial review by domestic courts; imposing strains on developing a sanctions regime which is aimed at reducing serious threats to global peace and security $y^{93}$; and finally, "tainting" administrative courts with the need to make a "defacto" normative choice between European and international law ${ }^{94}$.

The scenario above, which can also be relevant for constitutional courts in EU Member States, demonstrates not only the difficulties faced by

87 See, for example, Case of Al-Dulimi and Montana Mangement Inc. v. Switzerland (Application no. 5809/08).

88 Ibidem.

89 Art. 65-68, ICJ Statute.

90 Such advisory opinions might still have relevance even if the advisory functions of the ICJ are not similar to those of the CJEU, i.e. it is not entrusted with resolving preliminary questions on international law. For a discussion of past failed proposals to create such a mechanism for the ICJ, see T. Treves, "Advisory Opinions of the International Court of Justice on Questions Raised by Other International Tribunals", Max Planck UNYB, vol. 4, 2000, p. 215, p. 217-220.

91 For example, once faced with the notion that the ECtHR can hold that Article 103 to the UN Charter, which provides that Charter obligations have primacy to other international obligations (like the ECHR), is practically not sufficient to justify a violation of the ECHR. Al-Jedda v. the United Kingdom, 27021/08 (2009) ECHR 408, $100-109$.

92 Al-Dulimi and Montana Management Inc. v. Switzerland (Application no. 5809/08), Concurring Opinion of Judge Pinto de Albuquerque, Joined by Judges Hajiyev, Pelichal and Dedov, para. 58.

93 The sanctions regimes are imposed in accordance with Chapter 7 to the UN Charter, which can be applied if the Security Council determines, inter alia, that there has a been a "breach of peace" or a threat thereof.

94 P. Nevill, „Interpretation and Review of UN Sanctions by European Courts: Comity and Conflict", in: Research Handbook on UN Sanctions and International Law, L. van den Herik (ed.), 2017, p. 418, p. 438-439. 
administrative courts in addressing cross-border legal issues but also the emerging role of such courts in the global system, a function which they must acknowledge and cannot afford to ignore.

International Private Law - distinct from the previous examples, the relevance of constitutional and administrative courts in the international private law sphere, in the EU context, is less apparent. This is because private law matters can involve predominantly matters relating to civil procedure ${ }^{95}$ and the relevant EU regimes (Brussels Regimes) specifically exclude administrative matters from their application, limiting themselves to civil and commercial matters ${ }^{96}$. The ICJ also deals mostly with matters of public international law ${ }^{97}$, rendering it less relevant in this context for the scenarios discussed.

Taking into account these arguments, a closer look might indicate otherwise in a world of increasing interactions between norms and judicial institutions $s^{98}$. Referring to the arguments above by their order, the following can be noted: any decisions on applicable law or jurisdiction in cases of conflict can have implications on the right to access to justice ${ }^{99}$; it is far from clear what is the precise definition of commercial and civil matters in EU regimes ${ }^{100}$; and past decisions of the ICJ (and its predecessor the Permanent Court of International Justice) are of significance, even if limited, for the development of private international law ${ }^{101}$.

Under this framework, both types of courts can face the following (third) scenario. A defendant argues that a court in one Member State does not have jurisdiction to adjudicate a particular dispute because the choice

95 The importance of convergence of private law and civil procedure have led to initiatives for unification on regional European (and also global) level. See, for example, U. Box, The European Law Institute/UNIDROIT Civil Procedure Projects as a Soft Law Tool to Resolve Conflicts of Law, 2017, p. 5.

96 Article 1, Regulation (EU) No 1215/2012 of the European Parliament and the Council of 12 December 2012 on Jurisdiction and the Recognition and Enforcement of Judgments in Civil and Commercial Matters.

97 Note on "common courts" in Article 22 of the February 2017 draft Convention, para. 7, https://assets.hcch.net/docs/c168c7c4-e790-4551-993e-fe791ee0a1a6.pdf (accessed 23.11.2018).

98 This trend can be considered global but is especially relevant for the European legal order. R.A. Wessel, J. Wouters, “The Phenomenon of Multilevel Regulation: Interactions between Global, EU and National Regulatory Spheres", International Organisations Law Review, vol. 2, no 2, 2007, 257, p. 258-259.

99 Article 6 of the European Convention on Human Rights.

100 See, for example, the challenges posed by the question of classifying the issuance of government bonds. In Case C308/17, Request for a preliminary ruling under Article 267 TFEU from the Oberster Gerichtshof (Supreme Court, Austria), made by decision of 25 April 2017, received at the Court on 29 May 2017, in the proceedings of Hellenische Republik v. Leu Kohn (15 November 2018).

101 H. Van-Loon, "The Hague Conference on Private International Law", Hague Justice Journal, vol. 2, 2007, p. 12. 
of law and choice of court clause in a contract with an EU Member State (allegedly interpreted as indicating jurisdiction in another Member State or a non-exclusive clause) possibly acting in its sovereign capacity ${ }^{102}$ precludes the jurisdiction of the forum state. In the argument before the court, the defendant also argues that if the trial took place in the forum state, this would be in violation of his rights under the ECHR ${ }^{103}$.

This set of circumstances might be then referred to an administrative court to address the question of the definition of the state act as civil or administrative and to the constitutional court to decide about constitutional implications. Similarly to the two previous scenarios, albeit less directly, the courts would have to consider the following: the applicable EU and ECHR regimes, including the 2005 Choice of Court Convention to which all EU Member States are party; the case law of the CJEU on the definition of commercial and civil matters and the definition of sovereign acts of a state ${ }^{104}$; ICJ potential case law on issues such as choice of law ${ }^{105}$ and recognition and enforcement of foreign judgements ${ }^{106}$; and ECtHR and CJEU case law on access to justice ${ }^{107}$. Adding to the complexity, the courts will also need to consider the 2015 Hague Principles on Choice of Law in International Commercial Contracts (a non-binding list of principles yet still reflective of international practice $)^{108}$ as well asthe applicable domestic law and conflict of laws regimes.

Recalling that in private international law matters the role of administrative and constitutional courts in Europe is outside their traditional

102 See for example in the context of issuance of sovereign debts, Leu Kohn, Supra note 100 .

103 The issue could also come up in the context of a claim that applying foreign law to a domestic dispute can have discriminatory implications in a potential violation of Article 8 of the ECHR.

104 L. Kohn, Supra note 100.

105 See for example H. van Loon, The Role of the International Court of Justice in the Development of Private International Law, p. 4, http://www.asadip.org/wp-content/ uploads/2013/12/PILICJ-FINAL-DRAFT-Corr-180913-2.pdf (accessed 23.11.2018); PCIJ, A case concerning the payment of various Serbian loans issued in France (France v. The Kingdom of Serbs, Croats and Slovenes, 12 July 1929). Although this is a decision from almost a century ago, it demonstrates issues which can still be brought before the ICJ today.

106 Application Instituting Proceedings, Jurisdiction and Enforcements of Judgements in Civil and Commercial Courts (Belgium v. Switzerland, 21 December 2009). This case was discontinued but just in the Serbian Loans case, this application shows a potential for ICJ case law on a core private international law matter.

107 For an extensive debate see Handbook on European law relating to access to justice (2016), https://www.echr.coe.int/Documents/Handbook_access_justice_ENG. pdf (accessed 23.11.2018).

1082015 Hague Principles on Choice of Law in International Commercial Contracts, https://www.hcch.net/en/instruments/conventions/full-text/?cid=135 (accessed 23.11.2018). 
"comfort" zones ${ }^{109}$, the challenges presented are significant. In such cases, the courts would not only have to decide which norms or institutions prevail but equally to engage in judicial transnational dialogue between fields of international law which are arguably based on different rationales ${ }^{110}$, despite a recent convergence as noted by some scholars ${ }^{111}$.

Accordingly, this "perfect storm" scenario represents an important example of potential conflicts between the various applicable regimes. The implications of any choice the courts would make will not only be of significance for the particular issue at hand but are also likely to imply the formation of new and merged versions of international law combining elements from various doctrines and normative sources.

This last example and scenario highlight the global importance, alongside the more obvious domestic one, of finding a way to facilitate understanding by administrative and constitutional courts in Europe of the international context in which they operate as would be discussed in the next and final section of the paper.

\section{Principles for developing a roadmap}

Developing a road-map for resolving conflicts between different norms and judicial instances in the context of administrative and constitutional decision-making is quite a formidable endeavour. For this reason, the following ideas present only the beginning of a discussion on this complex matter, aiming to facilitate further study and debate.

Starting with the principal actors involved, i.e. the judges, the very basic important element is the awareness of their role as transnational actors on both European and global levels ${ }^{112}$. In practical terms, such awareness could lead to familiarity with applicable international norms and institutions, including their respective scopes, jurisdictions and case law.

109 This challenge is likely to continue to increase in the age of blurred lines between public and private law M. Rosenfeld, "Rethinking the Boundaries between Public Law and Private Law for the Twenty First Century: An Introduction”, International Journal of Constitutional Law vol. 11(1), 2013, p. 125-128.

110 The methodology of transnational judicial dialogues is a contemporary modern feature of modern juridical conduct, including in the European system, but is especially common in the context of international law, A. Reinisch, Introduction in The Privileges and Immunities of International Organizations in Domestic Courts, A. Reinisch (ed.), 2013, p. 1-4.

111 See for example the trend of a merger between private and public international law, R. Michales, "Public and Private International Law: German Views on Global Issues", Journal of Private International Law, vol. 4, no. 1, 2008, p. 121-122.

112 In the US context, see P. Schiff Berman, "Judges as Cosmopolitan Transnational Actors", Tulsa Journal of Comparative \& International Law, vol. 12(1), 2004, p. 101-102. 
One way in which this can be done, other than by judicial training, is to think "outside the domestic box" and engage in study of the way courts in other EU and non-EU states addressed similar issues ${ }^{113}$. By doing so, the courts would not only be engaging in comparative legal work but also participating in a transnational dialogue with other domestic, regional and international judicial instances ${ }^{114}$.

More direct approaches can be engagement and involvement in networks of judges under the auspices of international and regional judicial cooperation bodies ${ }^{115}$. As networks are today considered to be an important factor in the creation of international law, these platforms can facilitate not only cooperation between courts of different Member States but also have normative impacts ${ }^{116}$, as complementary to judicial rulings.

These directions, and similar others, can contribute to enhancing the quality of judicial decision-making in this complex intertwined EU-international law cases, as well as their international legitimacy. However, the most important notion is that when adjudicating issues which include these international consequences, domestic administrative and constitutional courts must not ignore the international realm even if they are not legally bound to address it (unlike the EU law dimension). While it is admittedly difficult, and possibly not correct in some of the cases, to expect the European courts to blindly abide by international law or by decisions of international, or even regional, courts, it is of importance that the decisions address them, or at the very least consider them, in the adjudication process.

The second type of actors involved in the framework are the EU Member States. In the face of increasing complexities faced by the courts over the question of whether international law should be supreme to national law and what the answer to this question might entail ${ }^{117}$, regulatory measures

113 The current President of the CJEU has made it clear that comparative law analysis is an "essential tool" employed by the CJEU, K. Lenaerts, K. Gutman, "The Comparative Law Method and the European Court of Justice: Echoes Across the Atlantic", The American Journal of Comparative Law, vol. 64, 2016, p. 841, p. 864.

114 Some argue that this should not be considered as "dialogue" as such and is unlikely to change basic fundamental approaches of domestic courts, D.S. Law, W.-Ch. Chang, "The Limits of Global Judicial Dialogue", Washington Law Review, vol. 86, 2011, p. 523, p. 575.

115 In the context of Europe this is already occurring to some extent. See for example the analysis in M. Claes, M. de Visser, "Are You Networked Yet? On Dialogues in European Judicial Networks", Utrecht Law Review, vol. 8(2), 2002, p. 100.

116 A. Cavnar, The Foreign Office Model Versus the Global Governance Model: An Introduction (2008), http://iilj.org/wp-content/uploads/2016/08/Cavnar-TheForeign-Office-Model-Versus-the-Global-Governance-Model-2008.pdf (accessed 1.12.2018), p. 7-8.

117 D. Bethlehem, The Supremacy of International Law - Part 1, https://www. ejiltalk.org/the-supremacy-of-international-law-part-one/, 2 June 2016 (accessed 2.12.2018). 
can be considered to clarify potential conflicts. In this regard, possible steps can include, inter alia, specifying in national law or the constitution what norms or bodies have primacy in the case of conflicts ${ }^{118}$; issuing flexible guidelines for judicial determination of disputes in the international legal context ${ }^{119}$, or specifically incorporating decisions of international or regional courts in domestic law.

These options are viable and might create legal clarity, making life easier for administrative and constitutional courts. Nevertheless, they carry with them the risk of leading to a further fragmentation of international $\mathrm{law}^{120}$ while raising questions about EU vs. Member State competence when it comes to external affairs (transformed after the entry into force of the Lisbon Treaty in 2009) ${ }^{121}$. If any steps are indeed taken, they would have to be carefully considered and balanced against these potential counterproductive consequences.

The third actor considered is the international community as a whole, i.e. members of the EU or the ECHR as supranational organisations. Since these actors are the creators of judicial bodies like the ICJ, CJEU and the ECHR, they have the power to modify their respective constitutive instruments. The result of such clarifications can be more precise conflict resolving rules determining the relationship between the different decision outcomes. These rules can, for example, specify in which fields one decision overrides the other, or even determine, through treaties, which norms to control ${ }^{122}$.

Unfortunately or not, from a practical perspective for such modifications to be effective they will require almost universal consensus as different

118 See for example Article 94 to the constitution of the Kingdom of the Netherlands, stipulating that: "Statutory regulations in force within the Kingdom shall not be applicable if such application is in conflict with provisions of treaties or of resolutions by international institutions that are binding on all persons."

119 It is important to note that, inherently, any guidance provided should be flexible, as envisioned by Articles 31-33 of the 1966 Vienna Convention on the Law of Treaties; H. Ph. Aust, A. Rodiles and P. Staubach, "Unity or Uniformity? Domestic Courts and Treaty Interpretation", Leiden Journal of International Law vol. 27(1), 2014, p. 75, p. 83.

120 According to some, international law fragmentation is not necessarily a negative phenomenon as it contributes to a multitude of approaches, including those of judicial nature, to the application of international law (which can enhance its legitimacy), See for example A. Peters, "The Refinement of International Law: From Fragmentation to Regime Interaction and Politicisation", International Journal of Constitutional Law, vol. 15, 2017, p. 671, p. 702-704.

121 See for example in respect of EC competence in private international law matters, G.-R. de Groot, J.-J. Kuipers, "The New Provisions on Private International Law in the Treaty of Lisbon", Maastricht Journal of European and Comparative Law, vol. 15(1), 2008, p. 111-112.

122 Such a normative change could provide, for example, primacy for the ICJ, For a brief discussion of this hierarchy based approach see Peters, supra note 120, 683-684. 
groups of states comprise members of the different judicial institutions, although EU Member States belong to them all. It is also important to note that even if this problem can be overcome, such uniform application and global order will likely never be wholesome and complete, and open to interpretation, thus not truly solving the different complexities.

Ultimately, as evident from these initial ideas and the associated risks, the issue which is the focus of this paper is not likely to be resolved by regulatory measures whether domestic, regional, or international. Consequently, judges will likely continue to play a central role in addressing the various conflicts, with awareness as a key component of the best administrative decisions and ones most sound in constitutional terms.

\section{Summary}

Mapping out the various challenges faced by administrative and constitutional courts in EU Member States when concerned with international law-related dilemmas is quite an impossible task, mainly due to the unforeseen range of facts, circumstances and norms which can apply.

Understanding this reality, the author has instead chosen to present case scenarios for such cases, in the context of utilisation of international law by domestic courts to resolve disputes. Aiming for the most complicated cases, the circumstances described in the scenarios might seem far-fetched, but the goal was to illustrate some potential conflicts, whose number is increasing as a by-product of globalisation and an influx of blurred boundaries between international public law, international human rights law and international private law.

As the EU is, resulting from the Lisbon Treaty and the expanded focus on a unitary EU external affairs policy, gaining competence in international law related fields ${ }^{123}$ and promoting its membership in international treaties ${ }^{124}$, conflicts faced by administrative and constitutional courts in EU Member States are only likely to be on a rapid rise.

Hopefully, the analysis presented in the paper, including its final section on proposals for addressing the conflicts and the risk associated with some of them, has provided some insight and food for thought. In that sense, the discussion was not only aimed at judges involved in the adjudication of such cases but also other relevant actors involved in policy-making as well

123 See for example in relation to international investment policy-related matters the analysis of a recent case before the CJEU, arguing that the Justice applied a "Realpolitik" - based approach see M. Cremona, "Shaping EU Trade Policy post-Lisbon: Opinion 2/15 of 16 May 2017", EU Constitutional Law Review, vol. 14, 2014, p. 231, p. 257-259.

124 See for example the accession of the EU to the 2005 Hague Choice of Court Convention in 2015, https://www.hcch.net/en/instruments/conventions/status-table/ ?cid=98 (accessed 8.12.2018). 
as academics with an interest in providing theoretical solutions to these very practical dilemmas.

\section{Bibliography}

Andrade G.F. de, "Comparative Judicial Review", Journal of Constitutional Law, vol. 3(3), 2001, p. 977, p. 979.

Aust H.Ph., Rodiles A., Staubach P., "Unity or Uniformity? Domestic Courts and Treaty Interpretation”, Leiden Journal of International Law, vol. 27(1), 2014.

Bakircioglu O., "The Right to Self-Defence in National and International Law: The Role of the Imminence Requirement", Indiana International \& Comparative Law Review, vol. 19, 2009.

Benedetti M., The Conseil d'Etat and Schengen in Global Administrative Law: The Casebook, S. Cassese, B. Carotti, L. Casini, E. Cavalieri \& E. MacDonald (eds.), 2012.

Bethlehem D., The Supremacy of International Law - Part 1, https://www.ejiltalk. org/the-supremacy-of-international-law-part-one/, 2 June 22016 (accessed 2.12.2018).

Box U., The European Law Institute/UNIDROIT Civil Procedure Projects as a Soft Law Tool to Resolve Conflicts of Law, 2017, p. 5.

Buckley Ebrey P., Walthall A., Pre-Modern East Asia to 1800: A Cultural, Social, and Political History, Cengage Learning 2014.

Cali B., "Influence of the ICCPR in the Middle East", in: The Human Rights Covenants at 50: Their Past, Present, and Future, D. Moeckli, H. Keller, C. Heri (eds.), 2018.

Callahan D.J., Medieval Church Norms and Fiduciary Duties in Partnership, Cardozo Law Review, vol. 26, 2004.

Cartabia M., Constitutional Courts between Constitutional Law and European Law, https://www.cortecostituzionale.it/documenti/relazioni_internazionali/relazioneCartabia.pdf (accessed 16.10.2018).

Cavnar A., The Foreign Office Model Versus the Global Governance Model: An Introduction (2008), http://iilj.org/wp-content/uploads/2016/08/Cavnar-The-Foreign-Office-Model-Versus-the-Global-Governance-Model-2008.pdf (accessed 1.12.2018).

Claes M., de Visser M., "Are You Networked Yet? On Dialogues in European Judicial Networks", Utrecht Law Review, vol. 8(2), 2002.

Constitutional Courts and European Integration - Science and Technique and Democracy, 2005, p. 169.

"Constitutional Courts and International Law: Revisiting the Transatlantic Divide", Harvard Law Review vol. 129, 2016.

Cremona M., "Shaping EU Trade Policy post-Lisbon: Opinion 2/15 of 16 May 2017", EU Constitutional Law Review, vol. 14, 2014.

Darak P., Administrative Justice in Europe, Report of Hungary, 2, http://www. aca-europe.eu/en/eurtour/i/countries/hungary/hungary_en.pdf (accessed 28.9.2018). 
de Groot G.-R., Kuipers J.-J., “The New Provisions on Private International Law in the Treaty of Lisbon", Maastricht Journal of European and Comparative Law, vol. 15(1), 2008.

Dupuy P.-M., "The Unity of Application of International Law at the Global Level and the Responsibility of Judges", European Journal of Legal Studies, vol. 1(2), 2007.

Eilers A., The Binding Effect of Federal Constitutional Court Decisions Upon Political Institutions (2003), 3, https://www.venice.coe.int/webforms/documents/ default.aspx?pdffile=CDL-JU(2003)018-e (accessed 16.10.2018).

Elleman B.A., "Foreword" in Piracy and Maritme Crime - Historical and Modern Case Studies, B.A. Elleman, A. Forbes, D. Rosenberg (eds.) 2010, V-VII.

Enders Ch., The Right to have Rights: The concept of human dignity in German Basic Law, Revista de Estudos Constitucionais, Hermenêutica e Teoria do Direito, vol. 2(1), 2010.

European Parliament Briefing - Counter-terrorist sanctions regimes Legal framework and challenges at UN and EU levels, (2016), p. 2, http://www.europarl.europa.eu/RegData/etudes/BRIE/2016/589864/EPRS_BRI(2016)589864_EN.pdf (accessed 11.11.2018).

"European Parliament Report - Standing Up for Your Right(s)", in: Europe Locus Standi Country Reports Annex IV (2012)

Finke J., "Soverign Immuniy: Rule, Comity or Something Else", European Journal of International Law, vol. 21(4), 2011.

Fox H., Web Ph., The Law of State Immunity, 2013.

Friedman L.M., The Legal System: A Social Science Perspective, 1987, p. 198.

Gavrilov V., "Modern Russian Approaches to Correlation of International and Domestic Law", Mediterranean Journal of Social Sciences, vol. 6, no. 5, 2015, p. 375, p. 376.

Global Administrative Law: The Casebook, S. Cassese, B. Carotti, L. Casini, El. Cavalieri \& E. MacDonald (eds.), 2012.

Guzman A.T., "A Compliance Based Theory of International Law", California Law Review, vol. 90, 2002.

Hoenloe-Oehringen D. Zu, "The Principle of Effective Legal Protection in German Administrative Law", in: The Principle of Effective Legal Protection in Administrative Law: A European Comparison, Z. Szente, K. Lachmayer (eds.), Taylor \& Francis Ltd, 2017.

International Law and Justice, http://www.un.org/en/sections/issues-depth/international-law-and-justice/ (accessed 26.9.2018).

Johnson T.A., "A Violation of Jus Cogens Norms as an Implicit Waiver of Immunity Under the Federal Sovereign Immunities Act", Maryland Journal of International Law, vol. 19, 1995.

Kiestra L.R., The Impact of the European Convention on Human Rights on Private International Law, 2014.

Kolb R., "The relationship between the international and the municipal legal order: reflections on the decision no 238/2014 of the Italian Constitution Court", Questions of International Law vol. II, 2014.

Komárek J., "National Constitutional Courts in the European Constitutional Democracy", International Journal of Constitutional Law, vol. 12(3), 2014. 
Komárek J., “The Place of Constitutional Courts in the EU”, European Constitutional Law Review, vol. 9, 2013.

$\mathrm{Ku}$ Julian G., "The Significance of China's Views on the Jus Cogens Exception to Foreign Government Official Immunity", Duke Journal of Comparative \& International Law, vol. 26, 2016, p. 503.

Kumm M., “The Legitimacy of International Law: A Constitutionalist Framework of Analysis", The European Journal of International Law, vol. 15, no. 5, 2004.

'Lai Oshitokunbo Oshisanya, An Almanac of Contemporary Judicial Restatements With Commentaries - The Basebook, $2^{\text {nd }}$ ed. 2015.

Langbein J., Transnationalization and Regulatory Change in the EU's Eastern Neighbourhood, London and New York: Routledge 2015.

Langley Hardy M.J., Modern Diplomatic Law, Manchester 1968.

Law D.S., Chang W-Ch., “The Limits of Global Judicial Dialogue”, Washington Law Review, vol. 86, 2011.

Lenaerts K., Gutman K., "The Comparative Law Method and the European Court of Justice: Echoes Across the Atlantic", The American Journal of Comparative Law, vol. 64, 2016.

Lobban M., "English Approaches to International Law", in: Time, History and International Law, M.C.R. Craven, M. Fitzmaurice, M. Vogiatzi (eds.) 2006.

Longobardo M., "The Italian Constitutional Court's ruling against state immunity when international crimes occur: thoughts on decision no. 238 of 2014", Melbourne Journal of International Law, vol. 16(1), 2015.

Manning J.F., "Textualism and the Equity of Statute”, Columbia Law Review, vol. $101,2001$.

Marchi-Uhel C., Ombudsperson, Security Council ISIL (Da'esh) and Al-Qaida Sanctions Committee, 2 June 2016, https://www.un.org/sc/suborg/sites/www.un.org. sc.suborg/files/02062016_cojur.pdf (accessed 10.11.2016).

Maruste R., "The Role of the Consitutional Court in Democratic Society", Juridica International, XIII, 2007.

Michaels R., "Does Brexit Spell the Death of Transnational Law?", German Law Journal, vol. 17, 2016.

Michales R., "Public and Private International Law: German Views on Global Issues", Journal of Private International Law vol. 4, no. 1, 2008.

Moon W.J., "The Original Meaning of the Law of Nations", The Virginia Journal of International Law, vol. 56, 2016.

Muzi L., "Administrative Due Process of Law in the Light of the Jurisprudence of EU Courts: A Quantitative and Qualitative Analysis", in: Research Handbook on EU Administrative Law, C. Harlow, P. Leino, G. della Cananea (eds.), Edward Elgar Pub, 2017.

Nevill P., "Interpretation and Review of UN Sanctions by European Courts: Comity and Conflict", in: Research Handbook on UN Sanctions and International Law, L. van den Herik (ed.), 2017.

Nollkaemper A., Nijman J.E., "Beyond the Divide", in: New Perspectives on the Divide Between National and International Law, A. Nollkaemper, J.E. Nijman (eds.), 2007. 
Opdebeek I., De Somer S., “The Duty to Give Reasons in European Legal Area: a Mechanism for Transparent and Accountable Administrative Decision-Making? A Comparison of Belgian, Dutch, French and EU Administrative Law", Rocznik Administracji Publicznej, vol. 2, 2016.

Parish M., "International Courts and the European Legal Order", European Journal of International Law, vol. 23(1), 2012, p. 141.

Payandeh M., Sauer H., "European Union: UN sanctions and EU fundamental rights", International Journal of Constitutional Law, vol. 7(2), 2009.

Peters A., "The Refinement of International Law: From Fragmentation to Regime Interaction and Politicisation", International Journal of Constitutional Law, vol. 15, 2017.

Pugh G.W., "Historical Approach to the Doctrine of Sovereign Immunity", Louisiana Law Review, vol. 13, no. 3, 1953.

Putnam L.T., Courts without Borders: Law, Politics, and US Extraterritoriality, Cambridge University Press, 2016.

Rachovitsa A., "Fragmentation of International Law Revisited: Insights, Good Practices and Lessons to Be Learned from the Case Law of the European Court of Human Rights", 1 February 2015, Leiden Journal of International Law, vol. 28, 2015.

Reinisch A., "Introduction" in The Privileges and Immunities of International Organizations in Domestic Courts, A. Reinisch (ed.), 2013.

Rogoff M.A., "Symposium: French and American Perspectives Towards International Law and International Institutions: Application of Treaties and the Decisions of International Tribunals in the United States and France: Reflections on Recent Practice", Maine Law Review, vol. 58, 2006.

Rosenfeld M., "Rethinking the Boundaries between Public Law and Private Law for the Twenty First Century: An Introduction", International Journal of Constitutional Law, vol. 11(1), 2013.

Scharf M.P., "Accelerated Formation of Customary International Law", Journal of International \& Comparative Law, vol. 20(2), 2014.

Schiff Berman P., "Judges as Cosmopolitan Transnational Actors", Tulsa Journal of Comparative \& International Law, vol. 12(1), 2004.

Skoczylas A., Swora M., "Administrative Judiciary in Poland in Search for Fairness and Efficiency - An Overview", Transylvanian Review of Administrative Sciences, vol. $19 \mathrm{E} / 2007$.

Study on Individual Access to Constitutional Justice (2010), https://www.venice. coe.int/WebForms/documents/default.aspx?pdffile=CDL-AD(2010)039rev-e (accessed 16.10.2018).

Suere A.L., "Administrative Litigation in England and Wales", in: Administrative Litigation Systems in Greater China and Europe, Y. Li (ed.), 2014.

The Stanford Encyclopedia of Philosophy, https://plato.stanford.edu/entries/sovereignty/, 25 March 2016 (accessed 23.9.2018).

Titel R., "Post-Communist Constitutionalism: A Transitional Perspective", Columbia Human Rights Law Review, vol. 26, 1994.

Treves T., "Advisory Opinions of the International Court of Justice on Questions Raised by Other International Tribunals", Max Planck UNYB, vol. 4, 2000. 
Van Loon H., “The Hague Conference on Private International Law”, Hague Justice Journal, vol. 2, 2007.

Van Loon H., The Role of the International Court of Justice in the Development of Private International Law, p. 4, http://www.asadip.org/wp-content/uploads/2013/12/PILICJ-FINAL-DRAFT-Corr-180913-2.pdf (accessed 23.11. 2018).

Weibel M., "Principles of Treaty Interpretation: Developed for and Applied by National Courts", in: The Interpretation of International Law by Domestic Courts: Uniformity, H.P. Aust, G. Nolte (eds.), 2016.

Wessel R.A., Wouters J., “The Phenomenon of Multilevel Regulation: Interactions between Global, EU and National Regulatory Spheres", International Organizations Law Review, vol. 2, no. 2, 2007.

Wet E. de, Holding the United Nations Security Council Accountable for Human Rights Violations through Domestic and Regional Courts: A Case of Be Careful What You Wish For?, https://www.eui.eu/Documents/DepartmentsCentres/ AcademyofEuropeanLaw/CourseMaterialsHR/HR2009/DeWet/DeWetBackgroundReading1.pdf (accessed 11.11.2018).

White C., National Constitutional Courts and the EU The Evolution of the Conseil Constitutionnel and the Bundesverfassungsgericht, 2014, p. 5.

Whittle D., "The Limits of Legality and the United Nations Security Council: Applying the Extra-Legal Measures Model to Chapter VII Action", European Journal of International Law vol. 26, 2015.

Woehrling J.-M., "Judicial Control of Administrative Authorities in Europe: Toward a Common Model”, Hrvatska Javna Uprava, god. 6. br. 3., 2006.

Woehrling J.-M., Protecting Legality: Public administration and judiciary in EU countries. How to conciliate executive accountability and judicial review?, 2009, http://www.sigmaweb.org/publications/42755351.pdf (accessed 5.10.2018).

Wyrozumska A., "Poland" in International Law and Domestic Legal Systems: Incorporation, Transformation and Persuasion, D. Shelton (ed.), Oxford Scholarship Online, 2011.

Ziemele I., The Significance of the European Convention for the Protection of Human Rights and Fundamental Freedoms in the Case-Law of the Constitutional Court of the Republic of Latvia (2 October 2017), http://www.satv.tiesa.gov.lv/ en/articles/the-significance-of-the-european-convention-for-the-protectionof-human-rights-and-fundamental-freedoms-in-the-case-law-of-the-constitutional-court-of-the-republic-of-latvia/ (accessed 7.9.2019).

Abstract

In present times, administrative and constitutional courts are called upon to apply international law. Approaching this task, they must perform a delicate balancing act between national law and domestic policies and international law, the latter sometimes originating from rulings of international tribunals such as the International Court of Justice. This is even more the case for courts in EU Member States, adding to the equation "Europeanised" international law as laid down by the Court of Justice of the European Union and the European Court of Human Rights.

The article analyses these challenges faced by constitutional and administrative courts in EU Member States when they need to apply public international law, international 
human rights law and private international law. Discussing each field, the author refers to real and hypothetical examples and case studies, highlighting potential points of conflict and convergence between the relevant case law. Utilising the findings of the analysis, the paper offers a road map for judges in EU Member States to navigate the international legal waters as they seek to achieve the most appropriate balance between domestic law, EU law and decisions of relevant regional and international tribunals.

Keywords: international law, Court of Justice of the European Union, administrative courts, constitutional courts, European Court of Human Rights, International Court of Justice, litigation, public international law, private international law

\section{Zeuropeizowane prawo międzynarodowe i administracyjne a trybunały konstytucyjne państw członkowskich UE: manewrując na globalnych wodach prawnych Luksemburga (Trybunał Sprawiedliwości Unii Europejskiej), Strasburga (Europejski Trybunał Praw (Złowieka) i Hagi (Międzynarodowy Trybunał Sprawiedliwości)}

Streszczenie

Obecnie często wzywa się sądy administracyjne oraz trybunały konstytucyjne do stosowania prawa międzynarodowego. Wykonując to zdanie, balansują one na cienkiej granicy, szukając równowagi pomiędzy prawem i politykami krajowymi a prawem międzynarodowym, którego źródłem bywają orzeczenia trybunałów międzynarodowych takich jak Międzynarodowy Trybunał Sprawiedliwości. Taka sytuacja często pojawia się w przypadku sądów państw członkowskich UE, do czego dochodzi jeszcze „zeuropeizowane" prawo międzynarodowe tworzone przez Trybunał Sprawiedliwości Unii Europejskiej oraz Europejski Trybunału Praw Człowieka. W artykule przeanalizowano wyzwania stające przed trybunałami konstytucyjnymi i sądami administracyjnymi w państwach członkowskich UE, które muszą stosować publiczne prawo międzynarodowe, międzynarodowe prawo praw człowieka oraz międzynarodowe prawo prywatne. Omawiając każdy z tych obszarów, autor przywołuje rzeczywiste i hipotetyczne przykłady jak też studia przypadków, podkreślając potencjalne obszary sporne oraz miejsca konwergencji w orzecznictwie. Wykorzystując swoje ustalenia, kreśli „mapę drogową” dla sędziów w państwach członkowskich UE, która ma im pomóc w manewrowaniu na międzynarodowych wodach prawnych i w wysiłkach zmierzających do zapewnienia jak najwłaściwszej równowagi pomiędzy prawem krajowym, przepisami unijnymi oraz decyzjami odpowiednich trybunałów regionalnych i międzynarodowych.

Słowa kluczowe: prawo międzynarodowe, Trybunał Sprawiedliwości Unii Europejskiej, sądy administracyjne, trybunały konstytucyjne, Europejski Trybunał Praw Człowieka, Międzynarodowy Trybunał Sprawiedliwości, spór sądowy, prawo międzynarodowe publiczne, prawo międzynarodowe prywatne 